\title{
Is reading a feminine domain? The role of gender identity and stereotypes in reading motivation in Chile
}

\author{
Ana María Espinoza ${ }^{1} \mathbb{D} \cdot$ Katherine Strasser $^{1}$
}

Received: 27 August 2019 / Accepted: 5 June 2020 / Published online: 22 June 2020

(c) The Author(s) 2020

\begin{abstract}
In Chile, as in other countries, there are large gender gaps in reading achievement. One factor that may explain some of these results is male and female students' motivation towards reading and books. The present study examined gender-related factors that contribute to explain students' reading motivation. One hundred and fifteen Chilean secondary students completed measures of reading motivation, gender identity and reading gender stereotypes. A multivariate analysis of variance showed that after controlling for language arts achievement, female students exhibited higher levels of reading motivation, in both dimensions: self-concept and value. Paired samples t-tests showed that all participants, male and female, viewed reading as a more feminine endeavor, revealing reading gender stereotypes. A multiple regression analysis showed that reading gender stereotypes explained significant variance in students' reading self-concept. Expressive identity traits (stereotypically feminine) as well as self-reported sexism both explained significant variance in the value that students associated with reading. The study offers empirical evidence about a relevant but understudied topic, especially in this region. These findings may contribute to the promotion of equal literacy development opportunities for students of both sexes in Latin America.
\end{abstract}

Keywords Gender identity $\cdot$ Stereotypes $\cdot$ Reading motivation $\cdot$ Self-concept

\section{Introduction and literature overview}

One central aim of educational policies worldwide is to achieve learning in all students, regardless of their social group (Organization for Economic Co-operation and Development [OECD] 2016). In Chile, this concern is particularly relevant given the wide gaps in academic achievement of different groups of students both in national

Ana María Espinoza

amespin1@uc.cl

1 School of Psychology, Pontificia Universidad Católica de Chile, Avda. Vicuña Mackenna 4860, Macul, Santiago, Chile 
and international tests (Educational Quality Agency 2018, 2019a, b; Mullis et al. 2016). Assessments in Chile and elsewhere in the world reveal that socioeconomic status (SES) and sex ${ }^{1}$ are the variables that best explain the lack of equity in learning (OECD 2016). Results show that students from higher socioeconomic levels obtain better results than those with poorer socioeconomic conditions; males outperform females in mathematics and sciences; and females, on the other hand, achieve higher scores in reading than males (OECD 2016).

Notwithstanding the above, in recent years the gender gap in mathematics has been narrowing in several countries (including the United States and Chile) (Educational Quality Agency 2019b; Hyde et al. 2008). However, in reading comprehension the gaps have remained stable and, in the case of Chile, they have widened, especially towards the end of the school trajectory (Educational Quality Agency 2019b). This situation is especially relevant considering that reading comprehension is a fundamental requirement for academic success (Connor et al. 2011; Snow 2002), as well as for participation in an increasingly literate society (Snow et al. 1998).

During the last decades, several international investigations have been carried out around this topic, identifying individual and contextual variables that may explain the gap. These variables include skills, attitudes towards different areas of knowledge, identity, gender stereotypes, beliefs and expectations of parents and teachers, and pedagogical practices. Regarding biological factors, it is noteworthy that although the neurosciences have identified some average differences in brain structure and functioning between men and women, there is no reliable way of dividing brains into "male" or "female" based on their morphology or function (Joel et al. 2015), and furthermore, there is no evidence that average brain sex differences are linked to learning (OECD 2007). In addition, there are few differences in verbal cognitive abilities between men and women (Hedges and Nowell 1995; Hyde and Linn 1988). All this would suggest that gender gaps in learning are more likely to be the result of socialization than of biological factors.

Despite the relevance of this issue, few studies have explored the social factors associated with the gender gap in favor of women in secondary education reading. Most of the research in Chile has focused on math gaps, and/or primary school. This study aims to contribute to the understanding of this phenomenon, focusing on the role of identity and gender stereotypes in the reading motivation of Chilean high school students.

\subsection{Differences between males and females in reading achievement}

The gender gaps in favor of females in reading achievement are well documented. The results of the 2016 PIRLS test (Progress in International Reading Literacy Study) revealed that in 48 of the 50 participating countries, fourth grade female

\footnotetext{
1 The term sex will be used to refer to the biological difference between men and women, and the term gender, to refer to socially constructed characteristics and roles, ascribed to the masculine and feminine (Barberá 1998).
} 
students had a better reading performance than boys. This gap has persisted since the origins of the test and has not been reduced in recent years (Mullis et al. 2017).

Additionally, the 2013 results of the Third Regional Comparative and Explanatory Study in Latin America and the Caribbean (TERCE), show that third grade females perform significantly better than males in reading and writing in all 15 participating Latin-American countries. In sixth grade, only in Ecuador and Guatemala, males present a slight advantage. In the case of Chile, a significant difference was found in favor of girls in both grade levels. This advantage was larger in sixth grade than in third grade, and it was larger than the regional gap (Gelber et al. 2016). Consistently, the latest results of Program for International Student Assessment (PISA) revealed that in the 79 countries evaluated there is a gap in favor of female 15-yearolds in reading (OECD 2019). In Chile that gap has remained steady during the last four evaluations (Educational Quality Agency 2019a, b).

In the same line, results of the 2018 Chilean "System for Measuring the Quality of Education" (SIMCE) showed a gap in favor of female students in reading comprehension in all the grade levels tested (4th, 6th, and 10th), which widens as students' progress in school. In addition, in recent years Chilean male students-especially those from high SES groups-have significantly decreased their reading scores, widening the gender gap even more (Educational Quality Agency 2019b).

Furthermore, although there are no significant differences in the results of Chilean male and female students in the language portion of the university selection test (Department of Evaluation, Measurement and Educational Registry 2016), Chilean students do exhibit sex differences in their choice of field of study. More men than women choose careers and jobs related to science, information, technology, and industry, and more women choose occupations related to social sciences, care of others, education, food and clothing (Nopo 2012; UNESCO 2012; United Nations Development Programme 2010; World Bank 2012).

\subsection{Factors associated with reading achievement}

How can these persistent achievement gaps be explained? Some of the factors that affect reading achievement, and which may affect males and females differently, are cognitive abilities (e.g. Hyde and Linn 1988); attitudes towards reading (e.g. Kelley and Decker 2009); gender identity (e.g. Kessels et al. 2014); teaching practices of parents (e.g. Sénéchal and Lefevre 2002) and teachers (e.g. Younger et al. 1999); parents' and teachers' beliefs about literacy (e.g. Sonnenschein et al. 1996; Wolter et al. 2015); the home environment (e.g. Strasser and Lissi 2009); gender stereotypes (e.g. Steffens and Jelenec 2011); and SES (e.g. Neuman 2006). Regarding these factors, the most explored so far have been contextual variables such as home literacy environment and teaching practices (e.g. Nag et al. 2019; Sénéchal and LeFevre 2014), or individual cognitive variables, whereas individual differences in the social dimension, such as beliefs or identity, have received less attention with regards to sex differences. However, sex differences in verbal cognitive skills are few (Hedges and Nowell 1995; Hyde and Linn 1988), while numerous studies show that there are sex differences in attitudes and beliefs toward reading (e.g. Heyder et al. 2017; 
McGeown 2015). In the next section we discuss what is known about sex differences in these non-cognitive variables related to reading achievement.

\subsection{Attitudes towards reading}

While differences in verbal cognitive abilities between men and women are few (Hedges and Nowell 1995; Hyde and Linn 1988), numerous studies show that there are sex differences in attitudes toward reading. One of the attitudinal variables that has been most studied, due to its important relationship with academic success, is motivation (Gutman and Schoon 2013). Research reveals that males feel less motivated and committed as readers than females (Baker and Wigfield 1999; McGeown 2015; Smith and Wilhelm 2002; Wigfield and Guthrie 1997), and that this intensifies with age (Kelley and Decker 2009; McKenna et al. 2012). The questionnaires of the PISA 2009 test confirmed the lower commitment to reading by male adolescents in the 65 participating countries (OECD 2010).

While there are many theories on motivation (Gutman and Schoon 2013), a model that has been widely used in the school context in relation to the gender gap, is the Expectancy-Value Theory (Eccles 1983; Wigfield and Eccles 2000). According to this theory, the performance, persistence and choices of individuals can be explained based on their expectations of how well they will do in a given activity, and on the value that they attribute to that activity. Task value encompasses the importance of the task for the self, the task interest, the task's utility, and the task's cost (in terms of time, effort, stress or loss of other valued elements). Expectations of achievement have to do with specific beliefs individuals have about their future success in a task, and are usually measured asking students how well they believe they could do a given task. Expectations of achievement frequently overlap with self-concept and self-efficacy regarding that task.

Expectancy-value theory has been tested mainly for math achievement (e.g. Meece et al. 1990). However, some studies show that beliefs about one's competence in language arts, together with task value, predict academic achievement and choice in that subject area as well (Eccles 1987; Eccles et al. 1994; Spinath et al. 2004; Watt 2004). Because girls tend to have a better self-concept in language than boys, and also value reading tasks more, expectancy-value theory is successful in explaining their higher performance in that area (Eccles et al. 1993; Jacobs et al. 2002; Kelley and Decker 2009; Marinak and Gambrell 2010; Wigfield et al. 1997). Accordingly, a recent study conducted in Germany that applied the expectancyvalue model showed that boys' underachievement in language in high school was explained by their academic self-concept and task value, in addition to their parents' perceptions. These findings indicate that students' motivational beliefs are relevant in explaining males' lower achievement in language arts (Heyder et al. 2017).

\subsection{Reading-related gender stereotypes (RGS)}

Because it predicts that beliefs about the importance of a task and about one's ability to accomplish it will influence motivation, expectancy-value theory is consistent with the possibility that academic gender stereotypes explain some differences in 
motivation and achievement between males and females (Halpern 2006; Martinot et al. 2011; Plante et al. 2009).

Gender stereotypes are defined as beliefs about the characteristics that men and women are likely to have, including skills, preferences and personality traits. Often, they are prescriptive beliefs as well, which reflect what men and women should be (Deaux and LaFrance 1998).

Studies of gender stereotypes about academic achievement have revealed that more mathematics skill is usually attributed to males (Cvencek et al. 2011), and more reading skill to women (Eccles et al. 1994; Freedman-Doan et al. 2000; Martinot et al. 2011; Steffens and Jelenec 2011). Consistently, academic gender stereotypes have been shown to predict academic self-concept, academic achievement, course choice, and career aspirations (Guimond and Roussel 2001; Halpern 2006; Martinot et al. 2011; Plante et al. 2009). Specifically regarding reading, studies with self-report questionnaires, implicit measures, and in-depth interviews, have revealed that high school students perceive tasks related to reading as feminine (Millard 1997; Plante et al. 2009; Steffens and Jelenec 2011).

The perception of reading tasks as more appropriate or easier for females could affect both the achievement expectations and perceived value of a task for males and females. Social Identity Theory (Tajfel 1974; Tajfel and Turner 1979) posits that membership in a group provides the basis for self-evaluation, and that intergroup comparisons can also play an important role in that process. In this way, the stereotype that women are better for reading than men (RGS), would have a positive effect on females' self-concept as readers, and a negative effect in that of males.

However, this process may very well be dependent on how much a person identifies with gender stereotypes. That is to say, if reading is considered a feminine endeavor because it is seen as a "reflexive" or "calm" activity, for example, and these traits are stereotypically associated with women, then a woman who for whatever reason does not identify as reflexive or calm, may be less affected by these readingrelated gender stereotypes. Therefore, it is possible that gender identity plays a relevant role on the way in which reading and gender stereotypes relate to each other.

\subsection{Gender identity}

Gender identity has been defined as the feeling a person has about being male or female (Barberá 1998; Egan and Perry 2001; Wood and Eagly 2009). It is linked to the degree to which a person considers as part of their identity the characteristics and roles socially assigned to men and women (Rocha-Sánchez 2009).

There are multiple theoretical perspectives about the development of gender identity. One that has gained importance in recent decades is the multifactorial theory of gender identity. This theory was elaborated by Spence (1993), and posits that gender identity has four components. The first component consists of masculinity and femininity traits, which are aligned with the categories of the instrumental (masculine) versus the expressive (feminine). The second component relates to gender stereotypes, the beliefs shared by a social group about activities, traits or attributes that distinguish men and women. The third components are gender roles, activities that are considered dominant 
or characteristic of one sex and are associated with a social role. The last component corresponds to attitudes towards gender roles, which refer to the evaluation of different roles that men and women are assigned (Rocha-Sánchez 2009). Regarding identification with so-called male and female traits, one of the most used instruments is the Bem Sex Role Inventory (BSRI; Bem 1974), which evaluates individuals' identification with traits that are high in instrumentality and/or agency (such as assertiveness, competitiveness and independence) and with traits linked to expressiveness and care of others (such as dependency, deference, cooperation and care) (Bem 1974).

Students' identification with traits that are stereotypically masculine or feminine may play a relevant role on their tendency to engage in different activities. The IdentityBased Motivation Theory (Elmore and Oyserman 2012), claims that individuals prefer to act in ways that feel in line with their social identities, such as gender identity. More specifically to gender, the Interests as Identity Regulation Model (Kessels et al. 2014) claims that individuals are more likely to be interested in domains that they perceive as fitting their gender identity, while they exclude themselves from those they consider to be discrepant. According to this theory, the stereotypes that associate reading with femininity would generate a mismatch between masculine gender identities and reading involvement, motivation, and perhaps even success.

Consistent with these views, McGeown et al. (2012) found that among 182 primary school students, intrinsic reading motivation was better explained by gender identity than by sex itself. However, Vantieghem et al. (2014a) obtained inconsistent results regarding gender identity and reading motivation. In a study with more than six thousand Flemish seventh graders, both boys and girls scored higher in reading self-efficacy when their gender identity matched their sex. According to the interests as identity regulation model, and if reading is considered a feminine activity, this result should be expected for girls, whereas for boys it is against what the model predicts. The authors explained this surprising result alluding to the lower wellbeing of both boys and girls who have lower gender typicality, because of the socially challenging position this creates for the youngsters. An alternative explanation, however, could be related to the degree to which students actually believe reading to be feminine or masculine (i.e. RGS), a factor that was not measured in that study. Conceivably, the strength of gender identity's association with reading motivation could vary depending on how much the student endorses stereotypes that view reading as a predominantly feminine activity. In the present study we seek to evaluate the joint contribution of gender identity and gender stereotypes in the reading motivation of male and female high school students. Additionally, this is the first study of this type conducted in a sample of Latin American secondary students, contributing to the generalization of previous results regarding the role of gender factors on reading motivation.

\section{Goals and hypotheses}

The present study seeks to identify the contribution of gender identity and readinggender stereotypes (RGS), to the reading motivation of Chilean high school students (reading self-concept and value), controlling for reading achievement and student' sex. 


\subsection{Specific goals}

1. Identify sex differences in students' reading self-concept and the value they give to reading.

2. Examine the presence and degree of adherence to reading-gender stereotypes in Chilean high school students.

3. Determine the contribution of students' gender identity and their adherence to reading-gender stereotypes to their self-concept and the value they place on reading, controlling for their general gender stereotypes (sexism).

\subsection{Hypotheses}

Consistent with previous research, we expect female students to exhibit a higher academic self-concept and to attribute greater value to reading than male students. We also expect high school students to endorse RGS, in the sense that they associate reading with females and attribute greater academic ability and a higher level of reading motivation to female students compared to males. Finally, we expect gender identity and RGS to contribute unique variance to reading motivation. Specifically, it is hypothesized that identification with expressive identity traits, will have a positive linear effect on the level of reading motivation of the total sample of students, while identification with the instrumental traits will have a negative effect. As for RGS, it is expected that female students who more strongly endorse RGS (that reading $=$ female) will exhibit higher reading motivation (reading self-concept and value), while male students who adhere more strongly to those stereotypes will experience the opposite effects. That is, the students' reading motivation will correlate with their belief that their own gender is associated with reading.

\section{Methodology}

\subsection{Design}

The study had a correlational-comparative design (Balluerka and Vergara 2002), with student sex as a grouping variable. Student SES was controlled by design, since all participants belong to medium-low SES schools. The Chilean educational system is one of the most socioeconomically segregated school systems in the world, and therefore there is very little SES variability within each type of school (Valenzuela et al. 2013).

\subsection{Participants}

Participants were 115 9th, 10th, 11th and 12th grade students (53\% female) from two urban schools in the Metropolitan Region of Chile. The schools were selected through personal contacts with teachers. Average age of students was 15.91 years $(S D=1.077)$, with a range of 14 to 19 years. 
Table 1 Internal consistency indices of the scales used

\begin{tabular}{lll}
\hline Instrument & Scale & Cronbach's alpha \\
\hline Reading Motivation Scale & Reading self-concept & 0.808 \\
& Value associated with reading & 0.824 \\
Gender Identity Inventory & Expressive traits & 0.887 \\
& Instrumental traits & 0.782 \\
& Sexism & 0.968 \\
Reading Gender Stereotypes Question- & RGS about skills & 0.840 \\
naire (RGS) & RGS about motivation & 0.814 \\
& Total RGS & 0.882 \\
\hline
\end{tabular}

\subsection{Instruments}

\subsubsection{Reading motivation}

An adaptation of the Motivation to Read Profile (Gambrell et al. 1996) was used. A version for primary students that had been validated in Chile (Navarro et al. 2018) was used as a base, and modifications were added from the revised version of the original instrument (Malloy et al. 2013), as well as from the version for adolescents (Pitcher et al. 2007). The resulting self-report questionnaire contains 20 four-point items. It consists of two scales that measure two dimensions of the expectancy-value theory (Eccles 1983; Wigfield and Eccles 2000): reading self-concept and value associated with reading. The first scale contains 10 items about how the student perceives him or herself, and how they think they are perceived by his or her peers with respect to reading skills. The second scale contains 10 items on the importance students attribute to reading, as well as their commitment to it (see "Appendix 2"). Cronbach's alpha in our sample was 0.808 for self-concept and 0.824 for value (Table 1 ).

\subsubsection{Reading-gender stereotypes (RGS)}

A questionnaire created for the purposes of this research was used, which measures explicit gender stereotypes regarding reading. This instrument asks participants to indicate which group - men or women - is better at and more inclined to certain activities ("Comparing men and women, who do you think...?"). The instrument has two scales. The first scale, Gender Stereotypes about Reading Skills (9 items), concerns the skills necessary to engage in different reading activities. The Gender Stereotypes about Reading Motivation Scale, which has 9 items, addresses reading preferences and values. Each item is scored in a seven-point scale as follows 1: men much more than women; 2 : men more than women; 3 : men a little more than women; 4: men and women alike, 5: women a little more than men; 6: women more than men; 7: women much more than men (see "Appendix 3"). Cronbach's alpha was 0.840 for the reading skills stereotypes scale, 0.814 for the motivation stereotypes scale, and 0.882 for the total scale (Table 1). In order for the scores to have the same meaning for males and 
females in our sample, we calculated the degree to which each student believes that their own gender has more reading skills and reading motivation. To do this, men's score was reversed. The scores thus generated we called "Total RGS recoded".

\subsubsection{Gender identity}

To assess gender identity, we used the scales of expressive and instrumental traits of the Gender Identity Inventory, developed by Rocha-Sánchez and Díaz-Loving (2011) with an adult Mexican population. These two scales include a total of 20 items, each of which consists of a trait. For each trait, participants are asked to evaluate the degree to which that trait is an attribute of themselves, in a five-point Likert scale. The traits were divided in instrumental (masculine) or expressive (feminine) according to the theoretical proposal of Bem Sex Role Inventory (BSRI; Bem 1974), which has shown good psychometric properties in different countries and age ranges, proving to be a suitable way to measure masculinity and femininity in different settings (for a review see Vafaei et al. 2014). Instrumental traits were Aggressive, Competitive, Objective, Reflective, Strong, Bossy, Risk-taking, Dominant, Self-sufficient, Independent and Assertive. The expressive traits, on the other hand, were Tender, Affectionate, Attentive, Sweet, Warm, Sentimental, Sympathetic, Complacent and Emotional (see "Appendix 4"). Each participant received an instrumental and an expressive score, depending on their identification with each set of traits. Internal consistency of the scales was alpha $=0.887$ for expressive traits scale and alpha $=0.782$ for the receptive traits scale (see Table 1 ).

\subsubsection{Sexism (general gender stereotypes)}

In order to isolate variance due to individuals' beliefs about gender and reading, from their beliefs in general gender stereotypes, a measure of general gender stereotypes, or sexism, was included in all analyses. To measure sexism we used two scales from the Gender Identity Inventory (Rocha-Sánchez and Díaz-Loving 2011): the general gender stereotypes scale, and the attitudes towards gender roles scale. The general gender stereotypes scale contains 36 statements about stereotypical characteristics of men and women. The attitudes towards gender roles scale consists of 21 items that require participants to evaluate their agreement with traditional roles assigned to men and women. Both are scored in a five-point Likert response format (1: totally disagree, 5: totally agree) (see "Appendix 4"). The two scales exhibited a very high correlation $(r=.758)$, so they were collapsed into a single sexism scale. The Cronbach's alpha was 0.968 (see Table 1).

\subsubsection{Reading achievement}

In order to control for the impact that previous achievement may have on the students' motivation, self-concept, values and attitudes, we used as a control the participants' previous year GPA in language arts, as informed directly by the school. In Chile, high school language arts focuses mostly on three main learning goals: literature (including narrative, lyrical and drama), reading comprehension (including 
comprehending different types of texts), and literacy for citizenship. In addition to the language arts grades, a teacher report was also used in order to control for impact of previous achievement on reading motivation. For this report, we asked each language art teacher to rank the students in their class in their reading skills.

\subsection{Procedure}

Principals were invited to participate in the study through email and were asked to sign a letter of authorization. Subsequently, the students were invited to participate, emphasizing the voluntary nature of participation and confidentiality of information. Students who agreed to participate signed an assent for minors and received a letter of informed consent for parents. Data collection was conducted during the school day in the students' classrooms. The surveys took about $1 \mathrm{~h}$ to complete. All procedures were in accordance with ethical standards and approved by the Social Sciences and Humanities Ethics review board at the main author's institution.

\subsection{Data analysis}

To achieve our first goal, we conducted a multivariate analysis of variance (MANOVA) and covariance (MANCOVA) with student' sex as a grouping variable and language arts GPA as a covariate. Because there was a large negative correlation between GPA and teacher ranking $(r=-.65)$, only the grade was used as an indicator of academic achievement.

For the second goal, a one-sample $t$ test was conducted to compare the total RGS and the two RGS subscales to the answer corresponding to the option "men and women alike" (same=4). In addition, a multivariate analysis of variance (MANOVA) was performed with the scales of the RGS questionnaire as a dependent variable and students`sex as a grouping variable, to evaluate gender differences in the level of RGS presented.

For the last goal, two hierarchical linear regression analyses were carried out, one for each reading motivation score (one for reading self-concept and one for reading value). In both cases, control variables were introduced first (student' sex, previous achievement (grades), and general sexism). In a second block the Gender identity variables (expressive traits and instrumental traits), and RGS were entered. In order to preserve degrees of freedom, we only used the total RGS score (recoded) in the regression analyses (See correlation matrix of variables in Appendix 1).

\section{Results}

\subsection{Assumptions check}

There was no autocorrelation in the residuals, given that the Durbin-Watson test value of the predictive model of reading self-concept was $2.26(p=.180)$, and for the value associated was $2.18(p=.342)$. The Index of Inflation of the Variance between 
predictors (VIF), indicate that there is no multicollinearity among the predictors used in models of both outcome variables, since all present values within acceptable ranges $(<2.19$, Cohen et al. 2014) (see Appendix 1). Finally, the distribution of the residuals of estimated models was normal.

\subsection{Descriptive and group comparison statistics}

Regarding the academic achievement of the participants, average language arts grade was $5.30(S D=.90)$ on a scale of 1.0 to 7.0 (the Chilean grade scale). Female students had significantly higher grades $(M E=5.49 ; S D=.95)$ than males $(M E=5.09$; $S D=.79)(t(113)=-2.507, p=.014)$.

On the other hand, mean reading self-concept was $2.67(S D=.46)$ and mean reading value was $2.76(S D=.49)$. Regarding group differences, reading motivation was higher for females both in self-concept $\left(F(1,113)=10.616, p=.001, \eta p^{2}=0.086\right)$, and value $\left(F(1,113)=25.851, p<.000, \eta p^{2}=.186\right)$. Controlling for grades, these sex differences remain for self- concept $\left(F(1,112)=6.543, p=.012, \eta p^{2}=.055\right)$, and also for value $\left(F(1,112)=19.801, p<.000, \eta p^{2}=.150\right)$,

Regarding the second goal, participants exhibited gender stereotypes associated with reading (RGS), both with regards to skills $t(114)=9.128, p<.000$ and motivation $t(114)=13.318, p<.000$, as well as in total score $t(114)=11.372, p<.000$. There were no differences between males and females in level of RGS about skills $(F(1,113)=.065, p=.800)$ nor in RGS about motivation $(F(1,113)=.585, p=.446)$.

Descriptive statistics are shown in Table 2.

\subsection{Results of multiple regression models}

Regression models explained significant variance in both reading self- concept $(F(6$, $108)=6.527 ; p=.000)$, and reading value $(F(6,108)=11.398, p=.000)$.

As shown in Table 3, the control variables (sex, grades, and general sexism) explain $18.1 \%$ of the variance in reading self-concept, which is significant $(F(3,111)=4,412, p=.000)$. Only student's sex and grade were significant predictors in this model, but not general sexism $\left(\beta_{\text {sex }}=0.165, t=1.888, p=.010\right.$; $\left.\beta_{\text {grades }}=0.128, t=2.635, p=.010 ; \beta_{\text {sexism }}=-0.111, t=-1.366, p=.175\right)$. When gender identity variables and RGS were added in model 2 , they explained an additional and significant $8.7 \%$ of variance in reading self-concept ( $F_{\text {change }}(3$, $108)=4.270, p=.007)$. In model 2 , student's sex and grades ceased to be significant predictors $\left(\beta_{\text {sex }}=0.013, t=0.109, p=.913 ; \beta_{\text {grades }}=0.093, t=1.966\right.$, $p=.052)$. After accounting for the other variables in the model, RGS was a significant predictor of reading self-concept $(\beta=0.168, t=2.079, p=.040)$, but not gender identity variables $\left(\beta_{\text {expressive }}=0.078, t=1.440, p=.153 ; \beta_{\text {instrumental }}=0.123\right.$, $t=1.789, p=.076)$. The final model explains $26.8 \%$ of the variance of reading self-concept $(F(6,108)=6.527, p=.000)$.

As for value associated with reading, the control variables (sex, grade, and general sexism) explain $33.0 \%$ of the variance, which is significant $(F(3,111)=18.281$, $p=.000)$. Only students' sex and their general sexism were significant predictors, 
Table 2 Descriptive statistics of variables of the study

\begin{tabular}{llll}
\hline & $\begin{array}{l}\text { Males } \\
\text { Media (SD) }\end{array}$ & $\begin{array}{l}\text { Females } \\
\text { Media (SD) }\end{array}$ & $\begin{array}{l}\text { Total } \\
\text { Media (SD) }\end{array}$ \\
\hline $\begin{array}{l}\text { Reading Motivation Scale } \\
\text { Reading self-concept }\end{array}$ & $2.528(0.429)$ & $2.798(0.455)^{* *}$ & $2.671(0.462)$ \\
Value associated with reading & $2.533(0.437)$ & $2.958(0.456)^{* *}$ & $2.759(0.494)$ \\
Total reading motivation & $2.530(0.387)$ & $2.878(0.420)^{* *}$ & $2.715(0.439)$ \\
Gender Identity Inventory & & & \\
Expressive traits & $3.218(0.766)$ & $3.371(0.781)$ & $3.299(0.775)$ \\
Instrumental traits & $2.948(0.644)$ & $2.949(0.630)$ & $2.948(0.634)$ \\
Sexism & $2.398(0.563)$ & $1.918(0.487)^{* *}$ & $2.144(0.575)$ \\
RGS questionnaire & & & $4.450(0.528)$ \\
RGS about skills & $4.436(0.476)$ & $4.461(0.573)$ & $4.565(0.536)$ \\
RGS about motivation & $4.525(0.556)$ & $4.601(0.516)$ & $4.507(0.478)$ \\
Total RGS & $4.480(0.471)$ & $4.531(0.487)$ & \\
\hline
\end{tabular}

$S D$ standard deviation

$* p<.005 ; * * p<.001$

but not grades $\left(\beta_{\text {sex }}=0.253, t=2.993, p=.003 ; \beta_{\text {grades }}=0.074, t=1.577, p=.118\right.$; $\beta_{\text {sexism }}=-0.297, t=-3.773, p=.000$ ). When gender identity variables and RGS were added in model 2 , they explained an additional and significant $7.9 \%$ of variance in reading value $\left(F_{\text {change }}(3,108)=4.830, p=.003\right)$. In model 2 , students' sex ceased to be significant, but not sexism $\left(\beta_{\text {sex }}=0.100, t=0.881, p=.380\right.$; $\left.\beta_{\text {sexism }}=-0.293, t=-3.781, p=.000\right)$. After accounting for the other variables in the model, only identification with expressive traits (feminine gender identity) was a significant predictor of reading value $(\beta=0.164, t=3.144, p=.000)$, while RGS only reached marginal significance $(\beta=0.138, t=1.780, p=.078)$. Identification with instrumental traits (masculine gender identity) was not a significant predictor of value associated with reading, after controlling for all other variables in the model $\left(\beta_{\text {instrumental }}=-0.024, t=-0.360, p=.719\right)$. The final model explains $40.9 \%$ of the variance of reading value $(F(6,108)=12.467, p=.000)$.

\section{Discussion}

According to our hypotheses and previous findings, in this study high-school female students presented a better reading self-concept and assigned more value to reading than male students (Eccles et al. 1993; Heyder et al. 2017; Jacobs et al. 2002; Kelley and Decker 2009; Marinak and Gambrell 2010; Wigfield et al. 1997). The motivation gap in favor of women remained for both self-concept and value even after controlling for academic achievement in language arts, indicating that the higher self-concept and value that high-school female students assign to reading is not entirely due to their actual performance or the feedback they get from their teachers. According to the expectancy-value theory, individuals who exhibit higher value and expectancy with regards to a given subject are more likely to get involved 
Table 3 Multiple linear regression models results

\begin{tabular}{|c|c|c|c|c|c|c|}
\hline & & \multicolumn{2}{|c|}{ Not standardized coefficients } & \multirow{2}{*}{$\begin{array}{l}\text { Standardized } \\
\text { coefficients } \\
\text { Beta }\end{array}$} & \multirow[t]{2}{*}{$\mathrm{T}$} & \multirow[t]{2}{*}{ Sig } \\
\hline & & Beta & Standard error & & & \\
\hline \multicolumn{7}{|c|}{ Reading self-concept models } \\
\hline \multirow{4}{*}{$\begin{array}{l}\text { Block } 1 \\
R^{2}=.181\end{array}$} & Intercept & 1.979 & .400 & & 4.954 & .000 \\
\hline & Student's sex & .165 & .087 & .179 & 1.888 & .062 \\
\hline & Grade & .128 & .048 & .248 & 2.635 & .010 \\
\hline & Sexism & -.111 & .081 & -.138 & -1.366 & .175 \\
\hline \multirow{7}{*}{$\begin{array}{l}\text { Block } 2 \\
R^{2}=.268\end{array}$} & Intercept & 1.021 & .470 & & 2.172 & .032 \\
\hline & Student's sex & .013 & .118 & .014 & .109 & .913 \\
\hline & Grade & .093 & .048 & .181 & 1.966 & .052 \\
\hline & Sexism & -.078 & .081 & -.096 & -.961 & .339 \\
\hline & Expressive traits & .078 & .054 & .131 & 1.440 & .153 \\
\hline & Instrumental traits & .123 & .069 & .169 & 1.789 & .076 \\
\hline & Total RGS recoded & .168 & .081 & .253 & 2.079 & .040 \\
\hline \multicolumn{7}{|c|}{ Value associated with reading models } \\
\hline \multirow{4}{*}{$\begin{array}{l}\text { Block 1 } \\
R^{2}=.330\end{array}$} & Intercept & 2.615 & .387 & & 6.767 & .000 \\
\hline & Student's sex & .253 & .085 & .257 & 2.993 & .003 \\
\hline & Grade & .074 & .047 & .134 & 1.577 & .118 \\
\hline & Sexism & -.297 & .079 & -.345 & -3.773 & .000 \\
\hline \multirow{7}{*}{$\begin{array}{l}\text { Block } 2 \\
R^{2}=.409\end{array}$} & Intercept & 1.944 & .452 & & 4.306 & .000 \\
\hline & Student's sex & .100 & .113 & .101 & .881 & .380 \\
\hline & Grade & .049 & .046 & .089 & 1.075 & .285 \\
\hline & Sexism & -.293 & .078 & -.341 & -3.781 & .000 \\
\hline & Expressive traits & .164 & .052 & .256 & 3.144 & .002 \\
\hline & Instrumental traits & -.024 & .066 & -.031 & -.360 & .719 \\
\hline & Total RGS recoded & .138 & .076 & .195 & 1.780 & .078 \\
\hline
\end{tabular}

Bold values indicate statistical significance $(<0.05)$ of each predictor

in those activities (Wigfield and Eccles 2000). Therefore, males' lower value and self-concept in reading could be one of the factors that maintains sex gaps in reading achievement.

Regarding the second hypothesis of this study, results reveal that both male and female high-school students hold the belief that women have more skills and motivation for reading than men, that is, both sexes exhibit reading-gender stereotypes (RGS). This is consistent with the findings of previous international studies (Millard 1997; Plante et al. 2009; Steffens and Jelenec 2011), and shows gender stereotyping of an area of knowledge that is central to learning (Connor et al. 2011; Snow 2002).

Regarding the role of RGS and gender identity on the different aspects of reading motivation, the results only partially support this study's hypothesis. After controlling for previous achievement, sex, and general sexism, RGS were relevant only for predicting reading self-concept, while gender identity-specifically feminine gender identity- was relevant only with regards to value associated with reading. 
In relation to RGS, it was observed that students who believe that their own gender is better and more prone to reading, tend to have a better reading self-concept, even after controlling for their actual reading school performance and their gender identity. These results are consistent with the expectancy-value theory, which posits that motivation is influenced by societal beliefs (Wigfield and Eccles 2000). These findings are also consistent with previous research conducted by Evans et al. (2011) with African-American adolescents in the United States. They found that in the literacy domain, girls' and boys' self-concepts were influenced by their general perceptions of the abilities of males and females. These findings imply that stereotypes about social groups held by adolescents influence their views of themselves, which would be consistent with social identity theory (Tajfel 1974; Tajfel and Turner 1979). The theory predicts that students that exhibit high levels of social identification and sense of belonging to a binary gender group, membership in that group, as well as intergroup comparisons, would provide a basis for self-evaluation. In this way, the stereotype that women are better for reading than men, would have a positive effect on women's self-concept as readers, and a negative effect in that of men. Social identity theory additionally predicts that the impact of stereotypes will be especially strong when gender stereotypes are salient. This raises the question of whether the effect of RGS on student self-concept that we observed here would be stronger in social contexts where the division between males and females is made more relevant, such as in segregated educational settings.

RGS did not have a significant effect on the value that students assigned to reading activities. This may be explained because our measure of RGS referred to skills and intrinsic motivation, not to the social importance of reading for boys and girls. Thus, students' beliefs that women are better readers as well as more inclined to read, did not influence their evaluation of the value of reading for themselves.

Regarding gender identity, this variable only exhibited a significant contribution to reading value, but not to reading self-concept. Specifically, students who identified more with expressive traits such as tender, sentimental, emotional, which have traditionally been associated with women, tended to find reading tasks more valuable. It is important to remember that this association persists even after controlling for sex, and that indeed, the contribution of sex to reading value is no longer significant in the final model. This is consistent with findings of previous studies that indicate that students' gender identity is a better predictor of reading motivation (McGeown 2015; McGeown et al. 2012) and writing (Pajares and Valiante 2001) than biological sex. Present results are concordant with both the interests-as-identity-regulation model (Kessels et al. 2014), as well as with identity-based motivation theory (Elmore and Oyserman 2012), in as much as both theories claim that people prefer to get involved and engaged in activities that are perceived as in-line with their social identities, such as gender identity. Considering that, on average, participants in this study did adhere to stereotypes that associate reading with being female, it was to be expected that their identification with stereotypically feminine traits would predict their evaluation of reading activities as valuable for them. According to the two aforementioned theoretical models, interest valuing reading can be a way for students who identify with feminine traits to demonstrate their feminine identity. 
One unexpected finding was that one of our control variables, sexism, had a significant negative contribution to the value assigned to reading activities. The sexism scale was added to control for general views about males and females, and it measured individuals' endorsement of general stereotypes about male and female traits, as well as their adherence to beliefs that males and females should have different roles. Our results indicate that, after controlling for their sex, previous reading achievement, beliefs about gender-reading associations, and their gender identity, students in our sample who endorsed gender stereotypes more strongly tended to value reading less. This was surprising because, whereas an association between reading stereotypes and reading motivation was expected, an association between general stereotypes and reading motivation was not. It is possible that this association represents a spurious relationship, since sexism tends to be associated with some cultural and personality variables that are also associated with reading habits. For example, sexism has been negatively associated with empathy, social dominance, authoritarianism, openness, and agreeableness (Hellmer et al. 2018), of which at least two (openness and agreeableness) have been positively associated with reading motivation (Medford and McGeown 2012). Therefore, it is possible that the negative association between general sexism and reading value in the present study is indexing the effects of other confounding factors.

\subsection{Limitations and future research}

The results of this study should be interpreted in light of its limitations. One of them is the small sample size. This not only limits the statistical power and robustness of the conclusions, but also prevents the analysis of men and women separately, which would allow evaluating whether sex moderates the relationship between gender variables and reading motivation. Previous research suggests that such moderation relationships may exist; for example, that the strength of the association between gender identity and self-efficacy may be different for boys and girls (Vantieghem et al. 2014b). Unfortunately, due to our small sample we were limited to testing main effects and could not assess such interactions. Another limitation of this study is the sociocultural homogeneity of the participants, given by the very segregated nature of the Chilean school system. It is possible that results may vary depending on school characteristics.

Future research should focus on expanding and generalizing these results, as well as developing educational applications. For example, in order to prevent negative effects of gender stereotypes on boys' reading self-concept, researchers may need to know at what point in the life cycle students begin to develop the belief that reading is a feminine activity, using longitudinal designs. It would also be interesting to explore the role played by the school institution, and particularly teachers, in reproducing or challenging RGS, through classroom observations (Espinoza and Taut 2016a). Finally, investigating the effect of RGS and gender identity directly on reading achievement would lend more validity to the model. 


\subsection{Conclusions}

Taken together, the findings of this study show that social constructions of gender can play a significant role in the reading motivation of adolescents, and they highlight the importance of incorporating gender identity theory in research on gender gaps in education. Specifically, focusing on gender identity variables could advance our understanding not only of differences between the sexes in students' motivation and achievement, but of differences within sex groups as well (Vantieghem et al. 2014b).

In terms of implications, and in line with what was proposed by Francis and Skelton (2005), men may present a better reading performance in contexts where gender stereotypes are less salient. In this sense, creating a school setting where there are fewer stereotypes and expectations about what women and men are supposed to like or be good at, could be a better way to support the reading achievement of male students, than trying to adapt the literacy curriculum and teaching practices to stereotypes of masculine subjects and gendered interests (Moss 2011). Interventions should focus on questioning beliefs that associate different areas of knowledge with gender (Espinoza and Taut 2016b), in order to promote equal literacy learning opportunities for men and women, thus mitigating negative effects on their educational trajectories (UNESCO 2012).

Acknowledgements We appreciate the support of Professor Hector Carvacho for his valuable comments and suggestions during the course of this study. We thank our research assistants, Josefina Melero and Valentina Palma for their valuable work.

Authors' contributions Both authors contributed to the study conception and design. Material preparation, data collection and analysis were performed by first author. The first draft of the manuscript was written by first author. Second author translated, edited and approved the final version.

Funding This study was partially funded by National Commission of Scientific and Technological Research (CONICYT) Doctoral Grant No. 21161779.

Availability of data and material The data that support the findings of this study are available from the corresponding author upon reasonable request.

\section{Compliance with ethical standards}

Conflict of interest The authors declare that they have no conflict of interest.

Ethics approval All procedures and instruments were approved by the institutional ethics review board at the main author's institution (Report Number 18013100) and with the 1964 Helsinki declaration and its later amendments or comparable ethical standards.

Consent to participate Legal guardians of all participants, as well as participants themselves, gave explicit consent for participation.

Consent for publication Legal guardians of all participants, as well as participants themselves, gave explicit consent for the study to be published.

Open Access This article is licensed under a Creative Commons Attribution 4.0 International License, which permits use, sharing, adaptation, distribution and reproduction in any medium or format, as long as you give appropriate credit to the original author(s) and the source, provide a link to the Creative 
Commons licence, and indicate if changes were made. The images or other third party material in this article are included in the article's Creative Commons licence, unless indicated otherwise in a credit line to the material. If material is not included in the article's Creative Commons licence and your intended use is not permitted by statutory regulation or exceeds the permitted use, you will need to obtain permission directly from the copyright holder. To view a copy of this licence, visit http://creativecommons.org/ licenses/by/4.0/.

\section{Appendix 1: Correlations matrix}

\begin{tabular}{|c|c|c|c|c|c|c|c|c|}
\hline & $\begin{array}{l}\text { Reading } \\
\text { self- } \\
\text { concept }\end{array}$ & $\begin{array}{l}\text { Value } \\
\text { associ- } \\
\text { ated with } \\
\text { reading }\end{array}$ & $\begin{array}{l}\text { Student's } \\
\text { sex }\end{array}$ & $\begin{array}{l}\text { Language } \\
\text { arts grade }\end{array}$ & $\begin{array}{l}\text { Total } \\
\text { RGS } \\
\text { recoded }\end{array}$ & $\begin{array}{l}\text { Expres- } \\
\text { sive traits }\end{array}$ & $\begin{array}{l}\text { Instru- } \\
\text { mental } \\
\text { traits }\end{array}$ & Sexism \\
\hline $\begin{array}{l}\text { Reading } \\
\text { self- } \\
\text { concept }\end{array}$ & - & $.689 * *$ & $.293 * *$ & $.345 * *$ & $.345^{* *}$ & $.272 * *$ & $.285^{* * *}$ & $-.313 * *$ \\
\hline $\begin{array}{l}\text { Value } \\
\text { associ- } \\
\text { ated } \\
\text { with } \\
\text { reading }\end{array}$ & $.689 * *$ & - & $.431 * *$ & $.332 * *$ & $.411 * *$ & $.346^{* *}$ & $.185^{*}$ & $-.507^{* *}$ \\
\hline $\begin{array}{l}\text { Student's } \\
\text { sex }\end{array}$ & $.293 * *$ & $.431 * *$ & - & $.227 *$ & $.728 * *$ & .099 & .002 & $-.419 * *$ \\
\hline $\begin{array}{l}\text { Language } \\
\text { arts } \\
\text { grade }\end{array}$ & $.345^{* *}$ & $.332 * *$ & $.227 *$ & - & $.244 * *$ & .161 & $.226^{*}$ & $-.405^{* *}$ \\
\hline $\begin{array}{c}\text { Total RGS } \\
\text { recoded }\end{array}$ & $.345^{* *}$ & $.411 * *$ & $.728 * *$ & $.244 * *$ & - & .108 & -.016 & $-.270 * *$ \\
\hline $\begin{array}{c}\text { Expres- } \\
\text { sive } \\
\text { traits }\end{array}$ & $.272 * *$ & $.346^{* *}$ & .099 & .161 & .108 & - & $.402 * *$ & -.167 \\
\hline $\begin{array}{l}\text { Instru- } \\
\text { mental } \\
\text { traits }\end{array}$ & $.285^{* *}$ & $.185^{*}$ & .002 & $.226^{*}$ & -.016 & $.402 * *$ & - & $-.280 * *$ \\
\hline Sexism & $-.313 * *$ & $-.507 * *$ & $-.419 * *$ & $-.405 * *$ & $-.270^{* *}$ & -.167 & $-.280 * *$ & - \\
\hline
\end{tabular}

$* p<.001$

$* * p<.005$

\section{Appendix 2: Reading Motivation Scale}

1. My friends believe that I am:

A very good reader

A good reader

$\square$ An average reader

A bad reader 
2. Reading a book is something that I like to do:

$\square$ Never

Almost never

$\square$ Sometimes

Frequently

3. I read:

Not as well as my friends

$\square$ Almost like my friends

$\square$ A little better than my friends

$\square$ A lot better than my friends

4. My best friends think that reading is:

Very entertaining

$\square$ Entertaining

$\square$ Ok

Boring

5. When I read and I find a word that I do not know:

$\square$ I almost always manage to work out its meaning

Sometimes I can work out its meaning

$\square$ I almost never work out its meaning

$\square$ I never work out its meaning

6. I tell my friends about good books that I read:

$\square$ Never

Almost never

$\square$ Sometimes

Many times

7. When I read alone I understand:

$\square$ Almost everything I read

Some of what I read

$\square$ Almost nothing of what I read

$\square$ Nothing I read

8. People who read a lot are:

Very interesting

$\square$ Interesting

$\square$ Boring

$\square$ Very boring

9. I am:

$\square$ A bad reader

An ok reader

A good reader

$\square$ A very good reader

10. I believe that libraries are:

A very good place to spend time

$\square$ A good place to spend time

$\square$ A boring place to spend time 
A very boring place to spend time

12. I worry about what people my age think about my reading:

Frequently

$\square$ Sometimes

$\square$ Almost never

Never

12. Knowing how to read well is:

Not important

$\square$ A little important

Important

$\square$ Very important

13. When my teacher asks me about what I have read:

I can never think of something to say

$\square \quad$ I almost never can think of something to say

$\square$ Sometimes I can think of something to say

I always know what to say

14. I think reading is:

$\square$ A boring way to spend time

An ok way to spend time

$\square$ An interesting way to spend time

$\square$ An excellent way to spend time

15. Reading is:

Very easy for me

$\square$ Somewhat easy for me

Somewhat difficult for me

Very difficult for me

16. When I am an adult:

$\square \quad$ I will not spend time reading

$\square$ I will spend very little time reading

$\square$ I will spend some time reading

$\square$ I will spend a lot of time reading

17. When I'm in a group talking about books I've read:

I hate to talk about my ideas

$\square$ I do not like to talk about my ideas

$\square$ I like to talk about my ideas

I love talking about my ideas

18. When my teacher reads books out loud I think it is:

Very entertaining

$\square$ Entertaining

$\square$ Boring

Very boring

19. When I read aloud I am a:

Bad reader

$\square$ Ok reader

$\square$ Good reader

$\square$ Very good reader 
20. If someone gave me a book for my birthday. I would feel:

Very happy

$\square$ Happy

$\square$ Unhappy

Very unhappy

\section{Appendix 3: Reading Gender Stereotypes Questionnaire (RGS)}

\begin{tabular}{|c|c|c|c|c|c|c|c|}
\hline $\begin{array}{l}\text { Comparing } \\
\text { men and } \\
\text { women. } \\
\text { Who } \\
\text { in your } \\
\text { opinion }\end{array}$ & $\begin{array}{l}\text { Men much } \\
\text { more }\end{array}$ & Men more & $\begin{array}{l}\text { Men a lit- } \\
\text { tle more }\end{array}$ & $\begin{array}{l}\text { Men and } \\
\text { women } \\
\text { alike }\end{array}$ & $\begin{array}{l}\text { Women a } \\
\text { little more }\end{array}$ & $\begin{array}{l}\text { Women } \\
\text { more }\end{array}$ & $\begin{array}{l}\text { Women } \\
\text { much more }\end{array}$ \\
\hline $\begin{array}{l}\text { 1. They } \\
\text { read fast }\end{array}$ & $\begin{array}{l}\text { Men much } \\
\text { more }\end{array}$ & Men more & $\begin{array}{l}\text { Men a lit- } \\
\text { tle more }\end{array}$ & Same & $\begin{array}{c}\text { Women } \\
\text { a little } \\
\text { more }\end{array}$ & $\begin{array}{c}\text { Women } \\
\text { more }\end{array}$ & $\begin{array}{c}\text { Women } \\
\text { much } \\
\text { more }\end{array}$ \\
\hline $\begin{array}{l}\text { 2. They } \\
\text { have a } \\
\text { hard time } \\
\text { under- } \\
\text { standing } \\
\text { what } \\
\text { they read }\end{array}$ & $\begin{array}{l}\text { Men much } \\
\text { more }\end{array}$ & Men more & $\begin{array}{l}\text { Men a lit- } \\
\text { tle more }\end{array}$ & Same & $\begin{array}{c}\text { Women } \\
\text { a little } \\
\text { more }\end{array}$ & $\begin{array}{c}\text { Women } \\
\text { More }\end{array}$ & $\begin{array}{c}\text { Women } \\
\text { much } \\
\text { more }\end{array}$ \\
\hline $\begin{array}{l}\text { 3. They } \\
\text { easily } \\
\text { identify } \\
\text { the cen- } \\
\text { tral idea } \\
\text { of a text }\end{array}$ & $\begin{array}{l}\text { Men much } \\
\text { more }\end{array}$ & Men more & $\begin{array}{l}\text { Men a lit- } \\
\text { tle more }\end{array}$ & Same & $\begin{array}{c}\text { Women } \\
\text { a little } \\
\text { more }\end{array}$ & $\begin{array}{c}\text { Women } \\
\text { more }\end{array}$ & $\begin{array}{c}\text { Women } \\
\text { much } \\
\text { more }\end{array}$ \\
\hline $\begin{array}{l}\text { 4. They } \\
\text { get better } \\
\text { grades in } \\
\text { reading }\end{array}$ & $\begin{array}{l}\text { Men much } \\
\text { more }\end{array}$ & Men more & $\begin{array}{l}\text { Men a lit- } \\
\text { tle more }\end{array}$ & Same & $\begin{array}{c}\text { Women } \\
\text { a little } \\
\text { more }\end{array}$ & $\begin{array}{c}\text { Women } \\
\text { More }\end{array}$ & $\begin{array}{c}\text { Women } \\
\text { much } \\
\text { more }\end{array}$ \\
\hline $\begin{array}{l}\text { 5. They } \\
\text { are often } \\
\text { wrong in } \\
\text { reading } \\
\text { compre- } \\
\text { hension } \\
\text { tasks }\end{array}$ & $\begin{array}{l}\text { Men much } \\
\text { more }\end{array}$ & Men more & $\begin{array}{l}\text { Men a lit- } \\
\text { tle more }\end{array}$ & Same & $\begin{array}{c}\text { Women } \\
\text { a little } \\
\text { more }\end{array}$ & $\begin{array}{c}\text { Women } \\
\text { more }\end{array}$ & $\begin{array}{c}\text { Women } \\
\text { much } \\
\text { more }\end{array}$ \\
\hline $\begin{array}{l}\text { 6. They } \\
\text { need } \\
\text { help to } \\
\text { under- } \\
\text { stand } \\
\text { complex } \\
\text { texts }\end{array}$ & $\begin{array}{l}\text { Men much } \\
\text { more }\end{array}$ & Men more & $\begin{array}{l}\text { Men a lit- } \\
\text { tle more }\end{array}$ & Same & $\begin{array}{c}\text { Women } \\
\text { a little } \\
\text { more }\end{array}$ & $\begin{array}{c}\text { Women } \\
\text { More }\end{array}$ & $\begin{array}{c}\text { Women } \\
\text { much } \\
\text { more }\end{array}$ \\
\hline
\end{tabular}




\begin{tabular}{|c|c|c|c|c|c|c|c|}
\hline $\begin{array}{l}\text { Comparing } \\
\text { men and } \\
\text { women. } \\
\text { Who } \\
\text { in your } \\
\text { opinion }\end{array}$ & $\begin{array}{l}\text { Men much } \\
\text { more }\end{array}$ & Men more & $\begin{array}{l}\text { Men a lit- } \\
\text { tle more }\end{array}$ & $\begin{array}{l}\text { Men and } \\
\text { women } \\
\text { alike }\end{array}$ & $\begin{array}{l}\text { Women a } \\
\text { little more }\end{array}$ & $\begin{array}{l}\text { Women } \\
\text { more }\end{array}$ & $\begin{array}{l}\text { Women } \\
\text { much more }\end{array}$ \\
\hline $\begin{array}{l}\text { 7. They } \\
\text { struggle } \\
\text { to read } \\
\text { well }\end{array}$ & $\begin{array}{l}\text { Men much } \\
\text { more }\end{array}$ & Men more & $\begin{array}{l}\text { Men a lit- } \\
\text { tle more }\end{array}$ & Same & $\begin{array}{c}\text { Women } \\
\text { a little } \\
\text { more }\end{array}$ & $\begin{array}{c}\text { Women } \\
\text { more }\end{array}$ & $\begin{array}{c}\text { Women } \\
\text { much } \\
\text { more }\end{array}$ \\
\hline $\begin{array}{l}\text { 8. They } \\
\text { find } \\
\text { reading } \\
\text { difficult }\end{array}$ & $\begin{array}{l}\text { Men much } \\
\text { more }\end{array}$ & Men more & $\begin{array}{l}\text { Men a lit- } \\
\text { tle more }\end{array}$ & Same & $\begin{array}{c}\text { Women } \\
\text { a little } \\
\text { more }\end{array}$ & $\begin{array}{c}\text { Women } \\
\text { More }\end{array}$ & $\begin{array}{c}\text { Women } \\
\text { much } \\
\text { more }\end{array}$ \\
\hline $\begin{array}{l}\text { 9. They } \\
\text { have the } \\
\text { facility } \\
\text { to read } \\
\text { complex } \\
\text { texts }\end{array}$ & $\begin{array}{l}\text { Men much } \\
\text { more }\end{array}$ & Men more & $\begin{array}{l}\text { Men a lit- } \\
\text { tle more }\end{array}$ & Same & $\begin{array}{c}\text { Women } \\
\text { a little } \\
\text { more }\end{array}$ & $\begin{array}{c}\text { Women } \\
\text { more }\end{array}$ & $\begin{array}{c}\text { Women } \\
\text { much } \\
\text { more }\end{array}$ \\
\hline $\begin{array}{l}\text { 10. They } \\
\text { like to } \\
\text { read }\end{array}$ & $\begin{array}{l}\text { Men much } \\
\text { more }\end{array}$ & Men more & $\begin{array}{l}\text { Men a lit- } \\
\text { tle more }\end{array}$ & Same & $\begin{array}{c}\text { Women } \\
\text { a little } \\
\text { more }\end{array}$ & $\begin{array}{c}\text { Women } \\
\text { More }\end{array}$ & $\begin{array}{c}\text { Women } \\
\text { much } \\
\text { more }\end{array}$ \\
\hline $\begin{array}{l}\text { 11. Read- } \\
\text { ing is } \\
\text { impor- } \\
\text { tant for } \\
\text { their } \\
\text { academic } \\
\text { and } \\
\text { personal } \\
\text { life }\end{array}$ & $\begin{array}{l}\text { Men much } \\
\text { more }\end{array}$ & Men more & $\begin{array}{l}\text { Men a lit- } \\
\text { tle more }\end{array}$ & Same & $\begin{array}{c}\text { Women } \\
\text { a little } \\
\text { more }\end{array}$ & $\begin{array}{c}\text { Women } \\
\text { more }\end{array}$ & $\begin{array}{c}\text { Women } \\
\text { much } \\
\text { more }\end{array}$ \\
\hline $\begin{array}{l}\text { 12. They } \\
\text { partici- } \\
\text { pate in } \\
\text { activi- } \\
\text { ties that } \\
\text { involve } \\
\text { reading }\end{array}$ & $\begin{array}{l}\text { Men much } \\
\text { more }\end{array}$ & Men more & $\begin{array}{l}\text { Men a lit- } \\
\text { tle more }\end{array}$ & Same & $\begin{array}{c}\text { Women } \\
\text { a little } \\
\text { more }\end{array}$ & $\begin{array}{c}\text { Women } \\
\text { More }\end{array}$ & $\begin{array}{c}\text { Women } \\
\text { much } \\
\text { more }\end{array}$ \\
\hline $\begin{array}{l}\text { 13. They } \\
\text { think that } \\
\text { reading } \\
\text { is inter- } \\
\text { esting }\end{array}$ & $\begin{array}{l}\text { Men much } \\
\text { more }\end{array}$ & Men more & $\begin{array}{l}\text { Men a lit- } \\
\text { tle more }\end{array}$ & Same & $\begin{array}{c}\text { Women } \\
\text { a little } \\
\text { more }\end{array}$ & $\begin{array}{c}\text { Women } \\
\text { more }\end{array}$ & $\begin{array}{c}\text { Women } \\
\text { much } \\
\text { more }\end{array}$ \\
\hline $\begin{array}{l}\text { 14. They } \\
\text { worry if } \\
\text { they do } \\
\text { not do } \\
\text { well in } \\
\text { reading }\end{array}$ & $\begin{array}{l}\text { Men much } \\
\text { more }\end{array}$ & Men more & $\begin{array}{l}\text { Men a lit- } \\
\text { tle more }\end{array}$ & Same & $\begin{array}{c}\text { Women } \\
\text { a little } \\
\text { more }\end{array}$ & $\begin{array}{c}\text { Women } \\
\text { More }\end{array}$ & $\begin{array}{c}\text { Women } \\
\text { much } \\
\text { more }\end{array}$ \\
\hline
\end{tabular}




\begin{tabular}{|c|c|c|c|c|c|c|c|}
\hline $\begin{array}{l}\text { Comparing } \\
\text { men and } \\
\text { women. } \\
\text { Who } \\
\text { in your } \\
\text { opinion }\end{array}$ & $\begin{array}{l}\text { Men much } \\
\text { more }\end{array}$ & Men more & $\begin{array}{l}\text { Men a lit- } \\
\text { tle more }\end{array}$ & $\begin{array}{l}\text { Men and } \\
\text { women } \\
\text { alike }\end{array}$ & $\begin{array}{l}\text { Women a } \\
\text { little more }\end{array}$ & $\begin{array}{l}\text { Women } \\
\text { more }\end{array}$ & $\begin{array}{l}\text { Women } \\
\text { much more }\end{array}$ \\
\hline $\begin{array}{l}\text { 15. They } \\
\text { will need } \\
\text { reading } \\
\text { to have } \\
\text { a good } \\
\text { job in the } \\
\text { future }\end{array}$ & $\begin{array}{l}\text { Men much } \\
\text { more }\end{array}$ & Men more & $\begin{array}{l}\text { Men a lit- } \\
\text { tle more }\end{array}$ & Same & $\begin{array}{c}\text { Women } \\
\text { a little } \\
\text { more }\end{array}$ & $\begin{array}{c}\text { Women } \\
\text { more }\end{array}$ & $\begin{array}{c}\text { Women } \\
\text { much } \\
\text { more }\end{array}$ \\
\hline $\begin{array}{l}\text { 16. They } \\
\text { read } \\
\text { many } \\
\text { books }\end{array}$ & $\begin{array}{l}\text { Men much } \\
\text { more }\end{array}$ & Men more & $\begin{array}{l}\text { Men a lit- } \\
\text { tle more }\end{array}$ & Same & $\begin{array}{c}\text { Women } \\
\text { a little } \\
\text { more }\end{array}$ & $\begin{array}{c}\text { Women } \\
\text { More }\end{array}$ & $\begin{array}{c}\text { Women } \\
\text { much } \\
\text { more }\end{array}$ \\
\hline $\begin{array}{l}\text { 17. They } \\
\text { find } \\
\text { reading } \\
\text { boring }\end{array}$ & $\begin{array}{l}\text { Men much } \\
\text { more }\end{array}$ & Men more & $\begin{array}{l}\text { Men a lit- } \\
\text { tle more }\end{array}$ & Same & $\begin{array}{c}\text { Women } \\
\text { a little } \\
\text { more }\end{array}$ & $\begin{array}{c}\text { Women } \\
\text { more }\end{array}$ & $\begin{array}{c}\text { Women } \\
\text { much } \\
\text { more }\end{array}$ \\
\hline $\begin{array}{l}\text { 18. They } \\
\text { are likely } \\
\text { to choose } \\
\text { a job that } \\
\text { requires } \\
\text { a lot of } \\
\text { reading }\end{array}$ & $\begin{array}{l}\text { Men much } \\
\text { more }\end{array}$ & Men more & $\begin{array}{l}\text { Men a lit- } \\
\text { tle more }\end{array}$ & Same & $\begin{array}{c}\text { Women } \\
\text { a little } \\
\text { more }\end{array}$ & $\begin{array}{c}\text { Women } \\
\text { More }\end{array}$ & $\begin{array}{c}\text { Women } \\
\text { much } \\
\text { more }\end{array}$ \\
\hline
\end{tabular}

\section{Appendix 4: Gender Identity Inventory}

I. Thinking of yourself, indicate how well each of the following characteristics describe you*:

\begin{tabular}{llllll}
\hline & Nothing & A little & Partially & Quite & Much \\
\hline 1. Aggressive [Agresivo/a] & 1 & 2 & 3 & 4 & 5 \\
2. Competitive [Competitivo/a] & 1 & 2 & 3 & 4 & 5 \\
3. Tender [Tierno/a] & 1 & 2 & 3 & 4 & 5 \\
4. Objective [Objetivo/a] & 1 & 2 & 3 & 4 & 5 \\
5. Affectionate [Cariñoso/a] & 1 & 2 & 3 & 4 & 5 \\
6. Reflexive [Reflexivo/a] & 1 & 2 & 3 & 4 & 5 \\
7. Attentive [Atento/a] & 1 & 2 & 3 & 4 & 5 \\
8. Sweet [Dulce] & 1 & 2 & 3 & 4 & 5 \\
9. Strong [Fuerte] & 1 & 2 & 3 & 4 & 5 \\
10. Warm [Cálido/a] & 1 & 2 & 3 & 4 & 5 \\
11. Bossy [Mandón/a] & 1 & 2 & 3 & 4 & 5 \\
12. Sentimental [Sentimental] & 1 & 2 & 3 & 4 & 5 \\
\hline
\end{tabular}




\begin{tabular}{llllll}
\hline & Nothing & A little & Partially & Quite & Much \\
\hline 13. Risk-taking [Arriesgado/a] & 1 & 2 & 3 & 4 & 5 \\
14. Sympathetic [Comprensivo/a] & 1 & 2 & 3 & 4 & 5 \\
15. Dominant [Dominante] & 1 & 2 & 3 & 4 & 5 \\
16. Self sufficient [Autosuficiente] & 1 & 2 & 3 & 4 & 5 \\
17. Complacent [Complaciente] & 1 & 2 & 3 & 4 & 5 \\
18. Independent [Independiente] & 1 & 2 & 3 & 4 & 5 \\
19. Emotional [Emocional] & 1 & 2 & 3 & 4 & 5 \\
20. Assertive [Asertivo/a] & 1 & 2 & 3 & 4 & 5 \\
\hline
\end{tabular}

*The words in square brackets indicate the original version of the instrument in Spanish

\section{Indicate your agreement with each of the following situations:}

\begin{tabular}{|c|c|c|c|c|c|}
\hline & $\begin{array}{l}\text { Strongly } \\
\text { disagree }\end{array}$ & Disagree & $\begin{array}{l}\text { Neither } \\
\text { agree nor } \\
\text { disagree }\end{array}$ & Agree & Strongly \\
\hline 1. That the man should set the rules of the home & 1 & 2 & 3 & 4 & 5 \\
\hline $\begin{array}{l}\text { 2. That the man should participate in the care of } \\
\text { the children }\end{array}$ & 1 & 2 & 3 & 4 & 5 \\
\hline $\begin{array}{l}\text { 3. That women should have the same freedom } \\
\text { as men }\end{array}$ & 1 & 2 & 3 & 4 & 5 \\
\hline 4. That the man should always have the last word & 1 & 2 & 3 & 4 & 5 \\
\hline $\begin{array}{l}\text { 5. That women should have job opportunities } \\
\text { similar to men }\end{array}$ & 1 & 2 & 3 & 4 & 5 \\
\hline $\begin{array}{l}\text { 6. That men and women should develop the same } \\
\text { tasks }\end{array}$ & 1 & 2 & 3 & 4 & 5 \\
\hline 7. That the woman should do the cooking & 1 & 2 & 3 & 4 & 5 \\
\hline $\begin{array}{l}\text { 8. That the man should expresses his emotions } \\
\text { just like a woman }\end{array}$ & 1 & 2 & 3 & 4 & 5 \\
\hline 9. That the woman should be self-sufficient & 1 & 2 & 3 & 4 & 5 \\
\hline 10. That the man should be the dominant one & 1 & 2 & 3 & 4 & 5 \\
\hline $\begin{array}{l}\text { 11. That the woman should develop personally } \\
\text { and professionally }\end{array}$ & 1 & 2 & 3 & 4 & 5 \\
\hline $\begin{array}{l}\text { 12. That women should participate in decision } \\
\text { making }\end{array}$ & 1 & 2 & 3 & 4 & 5 \\
\hline $\begin{array}{l}\text { 13. That the woman should take care of the } \\
\text { children }\end{array}$ & 1 & 2 & 3 & 4 & 5 \\
\hline $\begin{array}{l}\text { 14. That the man should spend time and play with } \\
\text { the children }\end{array}$ & 1 & 2 & 3 & 4 & 5 \\
\hline $\begin{array}{l}\text { 15. That the woman should dedicate herself to the } \\
\text { domestic tasks and stay at home }\end{array}$ & 1 & 2 & 3 & 4 & 5 \\
\hline $\begin{array}{l}\text { 16. That the woman should develop outside the } \\
\text { home }\end{array}$ & 1 & 2 & 3 & 4 & 5 \\
\hline
\end{tabular}




\begin{tabular}{|c|c|c|c|c|c|}
\hline & $\begin{array}{l}\text { Strongly } \\
\text { disagree }\end{array}$ & Disagree & $\begin{array}{l}\text { Neither } \\
\text { agree nor } \\
\text { disagree }\end{array}$ & Agree & Strongly \\
\hline $\begin{array}{l}\text { 17. That the man should be the strong part of the } \\
\text { relationship }\end{array}$ & 1 & 2 & 3 & 4 & 5 \\
\hline 18. That the man should take care of the children & 1 & 2 & 3 & 4 & 5 \\
\hline $\begin{array}{l}\text { 19. That the woman should be submissive and } \\
\text { sacrificed }\end{array}$ & 1 & 2 & 3 & 4 & 5 \\
\hline $\begin{array}{l}\text { 20. That the man should spend more time outside } \\
\text { the home }\end{array}$ & 1 & 2 & 3 & 4 & 5 \\
\hline $\begin{array}{l}\text { 21. That the success of man should lie in having } \\
\text { a paid job }\end{array}$ & 1 & 2 & 3 & 4 & 5 \\
\hline
\end{tabular}

III. Point out how much you agree with the following statements about men and women:

\begin{tabular}{|c|c|c|c|c|c|}
\hline & $\begin{array}{l}\text { Strongly } \\
\text { disagree }\end{array}$ & Disagree & $\begin{array}{l}\text { Neither } \\
\text { agree nor } \\
\text { disagree }\end{array}$ & Agree & Totally agree \\
\hline $\begin{array}{l}\text { 1. A woman does is not completely fulfilled } \\
\text { until she becomes a mother }\end{array}$ & 1 & 2 & 3 & 4 & 5 \\
\hline $\begin{array}{l}\text { 2. The man has better skills than the woman } \\
\text { for courtship }\end{array}$ & 1 & 2 & 3 & 4 & 5 \\
\hline $\begin{array}{l}\text { 3. Emotionally the woman possesses greater } \\
\text { strength than a man }\end{array}$ & 1 & 2 & 3 & 4 & 5 \\
\hline 4. The central axis of a family is the father & 1 & 2 & 3 & 4 & 5 \\
\hline 5. Being a man is better than being a woman & 1 & 2 & 3 & 4 & 5 \\
\hline $\begin{array}{l}\text { 6. It is easier for a man than for a woman to } \\
\text { court }\end{array}$ & 1 & 2 & 3 & 4 & 5 \\
\hline 7. Men are more aggressive than women & 1 & 2 & 3 & 4 & 5 \\
\hline $\begin{array}{l}\text { 8. The family works better if it is the man } \\
\text { who sets the rules of the home }\end{array}$ & 1 & 2 & 3 & 4 & 5 \\
\hline 9. Men are more rational than women & 1 & 2 & 3 & 4 & 5 \\
\hline $\begin{array}{l}\text { 10. Life is easier and happier for a man than } \\
\text { for a woman }\end{array}$ & 1 & 2 & 3 & 4 & 5 \\
\hline 11. A mother is more affectionate than a father & 1 & 2 & 3 & 4 & 5 \\
\hline $\begin{array}{l}\text { 12. Women have innate abilities for house- } \\
\text { work }\end{array}$ & 1 & 2 & 3 & 4 & 5 \\
\hline $\begin{array}{l}\text { 13. The ideal relationship between husband and } \\
\text { wife is one in which the man provides eco- } \\
\text { nomic support and the woman stays at home }\end{array}$ & 1 & 2 & 3 & 4 & 5 \\
\hline 14. Men are unfaithful by nature & 1 & 2 & 3 & 4 & 5 \\
\hline
\end{tabular}




$\begin{array}{lllll}\begin{array}{l}\text { Strongly } \\ \text { disagree }\end{array} & \begin{array}{c}\text { Disagree } \\ \text { Neither } \\ \text { agree nor } \\ \text { disagree }\end{array} & \text { Agree } & \text { Totally agree } \\ 1 & 2 & 3 & 4 & 5\end{array}$

$\begin{aligned} & \text { 15. Women have a greater capacity to care } \\ & \text { for the sick }\end{aligned}$
l6. A

16. A woman must be a virgin until marriage $1 \quad 3 \quad 2 \quad 3 \quad 4 \quad 5$

17. Women cannot perform the same activi- $11 \quad 2 \quad 3 \quad 4 \quad 5$ ties as men

18. All men must be risk takers and coura- $\quad 1 \quad 4 \quad 2 \quad 3 \quad 4 \quad 5$ geous

19. Even if a woman works outside the home, it is the man who has to take responsibility for supporting the family

20. A good wife should dedicate herself exclusively to her home and husband

21. A real man does not show his feelings and weaknesses

23. Children are better educated by a mother than by a father

24. Being a man implies greater responsibility than being a woman

25. A man is smarter than a woman

26. Life is harder for a man than for a woman

28. Infidelity is unforgivable in a woman

29. Men are less sensitive than women

30. Men like docile women

31. It is the man who must take charge of protecting the family

32. A real man is the one who has professional success

33. A man, unlike a woman, needs several 1 sexual partners

34. A good husband is the one who provides for the family financially

35. There are jobs in which men should have 1 preference over women for promotions

36. Women should recognize that there are 1 jobs for which they do not have the necessary psychological characteristics 


\section{References}

Baker, L., \& Wigfield, A. (1999). Dimensions of children's motivation for reading and their relations to reading activity and reading achievement. Reading Research Quarterly, 34(4), 452-477. https://doi. org/10.1598/RRQ.34.4.4.

Balluerka, N., \& Vergara, A. (2002). Designs of experimental research in psychology. Madrid: Prentice-Hall.

Barberá, E. (1998). Psicología del Género [Psychology of Gender]. I. M. Benlloch (Ed.). Barcelona: Ariel.

Bem, S. L. (1974). The measurement of psychological androgyny. Journal of Consulting and Clinical Psychology, 42(2), 155-162.

Cohen, P., West, S. G., \& Aiken, L. S. (2014). Applied multiple regression/correlation analysis for behavioral sciences. New York: Psychology Press.

Connor, C. M., Morrison, F. J., Fishman, B., Giuliani, S., Luc, M., Underwood, P. S., et al. (2011). Testing the impact of child characteristics $\times$ instruction interactions on third graders' reading comprehension by differentiating literacy instruction. Reading Research Quarterly, 46(3), 189221. https://doi.org/10.1598/RRQ.46.3.1.

Cvencek, D., Meltzoff, A. N., \& Greenwald, A. G. (2011). Math-gender stereotypes in elementary school children. Child Development, 82, 766-779. https://doi.org/10.1111/j.14678 624.2010.01529.x.

Deaux, K., \& LaFrance, M. (1998). Gender. In D. T. Gilbert, S. Fiske, \& G. Lindzey (Eds.), The handbook of social psychology (4th ed., pp. 788-827). New York: McGraw Hill.

Department of Evaluation, Measurement and Educational Registry (DEMRE) [Departamento de Evaluación, Medición y Registro Educacional]. (2016). Estadísticas sobre la rendición de pruebas 2016 [Test results report 2016]. Santiago: Author. Universidad de Chile: Vicerrectoría de Asuntos Académicos [University of Chile: Vice-rectory of Academic Affairs]. Retrieved from http:// www.psu.demre.cl/estadisticas/documentos-2016-compendio-p2016.

Eccles, J. S. (1983). Expectancies, values, and academic behaviors. In J. T. Spence (Ed.), Achievement and achievement motives: Psychological and sociological approaches (pp. 75-146). San Francisco, CA: Freeman.

Eccles, J. S. (1987). Gender roles and women's achievement-related decisions. Psychology of Women Quarterly, 11(2), 135-171.

Eccles, J. S., Wigfield, A., Harold, R. D., \& Blumenfeld, P. (1993). Age and gender differences in children's self- and task perceptions during elementary school. Child Development, 64(3), 830-847.

Eccles, J. S., et al. (1994). Understanding women's educational and occupational choices: Applying the Eccles et al. model of achievement-related choices. Psychology of Women Quarterly, 4, 585-609.

Educational Quality Agency [Agencia de Calidad de la Educación] (2019a). PISA 2018. Entrega de resultados [PISA 2018 Results] Retrieved from http://archivos.agenciaeducacion.cl/PISA_2018Entrega_de_Resultados_Chile.pdf.

Educational Quality Agency [Agencia de Calidad de la Educación] (2018). Resultados educativos 2017 [Educational results 2017]. Santiago: MINEDUC. Retrieved from http://archivos.agenciaeducacio n.cl/PPT_Conferencia_ER_2017_web_2.pdf.

Educational Quality Agency [Agencia de Calidad de la Educación] (2019b). Resultados educativos 2018 [Educational results 2018]. Santiago: MINEDUC. Retrieved from http://archivos.agenciaeducacio n.cl/Conferencia_EERR_2018.pdf.

Egan, S. K., \& Perry, D. G. (2001). Gender identity: A multidimensional analysis with implications for psychosocial adjustment. Developmental Psychology, 37, 451-463. https://doi. org/10.1037/0012-1649.37.4.451.

Elmore, K. C., \& Oyserman, D. (2012). If 'we' can succeed, 'I' can too: Identity-based motivation and gender in the classroom. Contemporary Educational Psychology, 37(3), 176-185. https://doi. org/10.1016/j.cedpsych.2011.05.003.

Espinoza, A. M., \& Taut, S. (2016a). El rol del género en las interacciones pedagógicas de aulas de matemática chilenas [The role of gender in pedagogical interactions in the Chilean mathematics classroom]. Psykhe, 25(2), 1-18. https://doi.org/10.7764/psykhe.25.2.858.

Espinoza, A. M., \& Taut, S. (2016b). El rol de género en las aulas chilenas [The role of gender in Chilean classrooms]. En J. Manzi, J., \& M. R., García (Eds.), Abriendo las puertas del aula: Transformación 
de las prácticas docentes [Opening the classroom door: transforming teaching practices] (pp. 449480). Santiago: Ediciones UC.

Evans, A. B., Copping, K., Rowley, S. J., \& Kurtz-Costes, B. (2011). Academic self-concept in Black adolescents: Do race and gender stereotypes matter? Self and Identity, 10, 263-277. https://doi. org/10.1080/15298868.2010.485358.

Francis, B., \& Skelton, C. (2005). Reassessing gender and achievement: Questioning contemporary key debates. London: Routledge.

Freedman-Doan, C., Wigfield, A., Eccles, J. S., Blumenfeld, P., Arbreton, A., \& Harold, R. D. (2000). What am I best at? Grade and gender differences in children's beliefs about ability improvement. Journal of Applied Developmental Psychology, 21(4), 379-402.

Gambrell, L., Palmer, B., Codling, R., \& Mazzoni, S. (1996). Assessing motivation to read. The Reading Teacher, 49(7), 518-533. https://doi.org/10.1598/RT.49.7.2.

Gelber, D., Treviño, E., \& Inostroza, P. (2016). Inequidad de género en los logros de aprendizaje en educación primaria. ¿Qué nos puede decir TERCE? [Inequality of gender in learning achievements in primary education. What can TERCE tell us?]. Santiago: Oficina Regional de Educación para América Latina y el Caribe [Regional Office of Education for Latin America and the Caribbean] (OREALC/UNESCO).

Guimond, S., \& Roussel, L. (2001). Bragging about one's grades: Gender stereotyping and students' perception of their abilities in science, mathematics and language. Social Psychology of Education, 4, 275-293. https://doi.org/10.1023/A:1011332704215.

Gutman, L. M., \& Schoon, I. (2013). The impact of non-cognitive skills on outcomes for young people. London: Education Empowerment Foundations.

Halpern, D. F. (2006). Assessing gender gaps in learning and academic achievement. In P. A. Alexander \& P. H. Winne (Eds.), Handbook of educational psychology (2nd ed.). Mahwah, NJ: Lawrence Erlbaum Associates.

Hedges, L. V., \& Nowell, A. (1995). Sex differences in mental test scores, variability, and numbers of high-scoring individuals. Science, 269(5229), 41-45. https://doi.org/10.1126/science.7604277.

Hellmer, K., Stenson, J. T., \& Jylhä, K. M. (2018). What's (not) underpinning ambivalent sexism? Revisiting the roles of ideology, religiosity, personality, demographics, and men's facial hair in explaining hostile and benevolent sexism. Personality and Individual Differences, 122, 29-37. https://doi. org/10.1016/j.paid.2017.10.001.

Heyder, A., Kessels, U., \& Steinmayr, R. (2017). Explaining academic-Track boys' underachievement in language grades: Not a lack of aptitude but students' motivational beliefs and parents' perceptions? British Journal of Educational Psychology, 87(2), 205-223. https://doi.org/10.1111/bjep.12145.

Hyde, J., Lindberg, S., Linn, M., Ellis, A., \& Williams, C. (2008). Gender similarities characterize math performance. Science, 321(5888), 494-495. https://doi.org/10.1126/science.1160364.

Hyde, J. S., \& Linn, M. C. (1988). Gender differences in verbal ability: A meta-analysis. Psychological Bulletin, 104, 53-69. https://doi.org/10.1037/0033-2909.104.1.53.

Jacobs, J. E., Lanza, S., Osgood, D., Eccles, J. S., \& Wigfield, A. (2002). Changes in children's self competence and values: Gender and domain differences across grades one through twelve. Child Development, 73(2), 509-527. https://doi.org/10.1111/1467-8624.00421.

Joel, D., Berman, Z., Tavor, I., Wexler, N., Gaber, O., Stein, Y., et al. (2015). Sex beyond the genitalia: The human brain mosaic. Proceedings of the National Academy of Sciences, 112(50), 15468-15473. https://doi.org/10.1073/pnas.1509654112.

Kelley, M. J., \& Decker, E. O. (2009). The current state of motivation to read between middle school students. Reading Psychology, 30(5), 466-485. https://doi.org/10.1080/02702710902733535.

Kessels, U., Heyder, A., Latsch, M., \& Hannover, B. (2014). How gender differences in academic engagement relate to students' gender identity. Educational Research, 56(2), 220-229. https://doi. org/10.1080/00131881.2014.898916.

Malloy, J. A., Marinak, B. A., Gambrell, L. B., \& Mazzoni, S. A. (2013). Assessing motivation to read. The Reading Teacher, 67(4), 273-282. https://doi.org/10.1002/trtr.1215.

Marinak, B. A., \& Gambrell, L. B. (2010). Reading motivation: Exploring the elementary gender gap. Literacy Research and Instruction, 49(2), 129-141. https://doi.org/10.1080/19388070902803795.

Martinot, D., Bages, C., \& Desert, M. (2011). French children's awareness of gender stereotypes about mathematics and reading: When girls improve their reputation in math. Sex Roles, 66, 210-219. https://doi.org/10.1007/s11199-011-0032-3.

McGeown, S. P. (2015). Sex or gender identity? Understanding children's reading choices and motivation. Journal of Research in Reading, 38(1), 35-46. https://doi.org/10.1111/j.1467-9817.2012.01546.x. 
McGeown, S., Goodwin, H., Henderson, N., \& Wright, P. (2012). Gender differences in reading motivation: Does gender or gender identity provide a better account? Journal of Research in Reading, 35(3), 328-336. https://doi.org/10.1111/j.1467-9817.2010.01481.x.

McKenna, M. C., Conradi, K., Lawrence, C., Jang, B. G., \& Meyer, J. P. (2012). Reading attitudes of middle school students: Results of a US survey. Reading Research Quarterly, 47(3), 283-306. https ://doi.org/10.1002/rrq.021.

Medford, E., \& McGeown, S. P. (2012). The influence of personality characteristics on children's intrinsic reading motivation. Learning and Individual Differences, 22(6), 786-791. https://doi.org/10.1016/j. lindif.2012.06.002.

Meece, J. L., Wigfield, A., \& Eccles, J. S. (1990). Predictors of math anxiety and its influence on young adolescents' course enrollment intentions and performance in mathematics. Journal of Educational Psychology, 82(1), 60-70. https://doi.org/10.1037/0022-0663.82.1.60.

Millard, E. (1997). Differently literate: Gender identity and the construction of the developing reader. Gender and Education, 9(1), 31-48. https://doi.org/10.1080/09540259721439.

Moss, G. (2011). Policy and the search for explanations for the gender gap in literacy attainment. Literacy, 45(3), 111-118.

Mullis, I. V. S., Martin, M. O., Foy, P., \& Hooper, M. (2016). TIMSS 2015 international results in mathematics. Retrieved from http://timssandpirls.bc.edu/timss2015/international-results/.

Mullis, I. V. S., Martin, M. O., Foy, P., \& Hooper, M. (2017). PIRLS 2016 international results in reading. Retrieved from http://timssandpirls.bc.edu/pirls2016/international-results/.

Nag, S., Vagh, S. B., Dulay, K. M., \& Snowling, M. J. (2019). Home language, school language and children's literacy attainments: A systematic review of evidence from low-and middle-income countries. Review of Education, 7(1), 91-150.

Navarro, M., Orellana, P., \& Baldwin, P. (2018). Validation of the reading motivation scale in Chilean elementary school students. Psykhe, 27(1), 1-17. https://doi.org/10.7764/psykhe.27.1.1078.

Neuman, S. B. (2006). The knowledge gap: Implications for early education. In D. Dickinson \& S. B. Neuman (Eds.), Handbook of early literacy research (Vol. 2, pp. 29-40). New York: Guilford.

Nopo, H. (2012). New century, old disparities: Gender and ethnic earnings gaps in Latin America and the Caribbean. Washington, DC: Inter-American Development Bank/World Bank.

Organization for Economic Co-Operation and Development (OECD). (2007). Understanding the brain: The birth of a learning science. Paris: OECD Publishing, PISA.

Organization for Economic Co-operation and Development (OECD). (2010). PISA 2009 results: Learning to learn: Student engagement, strategies and practices (Vol. 3). Paris: PISA, OECD Publishing. https:// doi.org/10.1787/9789264083943-en.

Organization for Economic Co-operation and Development (OECD). (2016). PISA 2015 results: Excellence and equity in education (Vol. 1). Paris: PISA, OECD Publishing. https://doi.org/10.1787/9789264266 490-en.

Organization for Economic Co-operation and Development (OECD). (2019). PISA 2018 results (Volume II): Where all students can succeed. Paris: PISA, OECD Publishing. https://doi.org/10.1787/b5fd1 b8f-en.

Pajares, F., \& Valiante, G. (2001). Gender differences in writing motivation and achievement of middle school students: A function of gender orientation? Contemporary Educational Psychology, 26(3), 366-381.

Pitcher, S. M., Albright, L. K., DeLaney, C. J., Walker, N. T., Seunarinesingh, K., Mogge, S., et al. (2007). Assessing adolescents' motivation to read. Journal of Adolescent \& Adult Literacy, 50(5), 378-396. https://doi.org/10.1598/JAAL.50.5.5.

Plante, I., Théorêt, M., \& Favreau, O. E. (2009). Student gender stereotypes: Contrasting the perceived maleness and femaleness of mathematics and language. Educational Psychology, 29(4), 385-405. https:// doi.org/10.1080/01443410902971500.

Rocha-Sánchez, T. E. (2009). Desarrollo de la identidad de género desde una perspectiva psico-socio-cultural: un recorrido conceptual [Development of gender identity from a psycho-socio-cultural perspective: A conceptual journey]. Interamerican Journal of Psychology, 43(2), 250-259.

Rocha-Sánchez, T. E., \& Díaz-Loving, R. (2011). Desarrollo de una escala para la evaluación multifactorial de la identidad de género en población mexicana [Development of a scale for the multifactorial evaluation of gender identity in the Mexican population]. Revista de Psicología Social, 26(2), 191-206.

Sénéchal, M., \& Lefevre, J. M. (2002). Parental involvement in the development of children's reading skills: A five-year longitudinal study. Child Development, 73, 445-460. https://doi.org/10.1111/14678624.00417. 
Sénéchal, M., \& LeFevre, J. (2014). Continuity and change in the home literacy environment as predictors of growth in vocabulary and reading. Child Development, 85(4), 1552-1568.

Snow, C. E. (2002). Reading for understanding: Toward a $R \& D$ program in reading comprehension. Santa Monica, CA: RAND.

Snow, C. E., Burns, M. S., \& Griffin, P. (Eds.). (1998). Preventing reading difficulties in young children. Washington, DC: National Academy Press.

Sonnenschein, S., Brody, G., \& Munsterman, K. (1996). The influence of family beliefs and practices on children's early reading development. In L. Baker, P. Afflerbach, \& D. Reinking (Eds.), Developing engaged readers in school and home communities (pp. 3-20). Mahwah, NJ: Lawrence Erlbaum.

Spence, J. (1993). Gender-related traits and gender ideology: Evidence for a multifactorial theory. Journal of Personality and Social Psychology, 64, 624-635.

Spinath, B., Spinath, F. M., Harlaar, N., \& Plomin, R. (2004). Predicting school achievement from general cognitive ability, self-perceived ability, and intrinsic value. Intelligence, 34(4), 363-374. https://doi. org/10.1016/j.intell.2005.11.004.

Steffens, M. C., \& Jelenec, P. (2011). Separating implicit gender stereotypes regarding math and language: Implicit ability stereotypes are self-serving for boys and men, but not for girls and women. Sex Roles, 64, 324-335. https://doi.org/10.1007/s11199-010-9924-X.

Strasser, K., \& Lissi, M. R. (2009). Home and instruction effects on emergent literacy in a sample of Chilean kindergarten children. Scientific Studies of Reading, 13(2), 175-204.

Tajfel, H. (1974). Social identity and intergroup behavior. Social Science Information, 13, 65-93.

Tajfel, H., \& Turner, J. (1979). An integrative theory of intergroup conflict. In S. Worchel \& W. G. Austin (Eds.), The social psychology of intergroup relations (pp. 33-48). Pacific Grove, CA: Brooks/Cole.

UNESCO. (2012). World Atlas of gender equality in education. Paris: UNESCO Editions.

United Nations Development Programme. (2010). Desarrollo humano en Chile: género los desafios de la igualdad [Human development in Chile: Gender the challenges of equality]. Santiago: United Nations Development Programme.

Vafaei, A., Alvarado, B., Tomás, C., Muro, C., Martinez, B., \& Zunzunegui, M. V. (2014). The validity of the 12-item Bem Sex Role Inventory in older English population: An examination of the androgyny model. Archives of Gerontology and Geriatrics, 59(2), 257-263.

Valenzuela, J. P., Bellei, C., \& de los Ríos, D. (2013). Socioeconomic school segregation in a market-oriented educational system: The case of Chile. Journal of Education Policy, 19, 217-241. https://doi. org/10.1080/02680939.2013.806995.

Vantieghem, W., Vermeersch, H., \& Van Houtte, M. (2014a). Transcending the gender dichotomy in educational gender gap research: The association between gender identity and academic self-efficacy. Contemporary Educational Psychology, 39(4), 369-378. https://doi.org/10.1016/j.cedpsych.2014.10.001.

Vantieghem, W., Vermeersch, H., \& Van Houtte, M. (2014b). Why "gender" disappeared from the gender gap: (Re-)introducing gender identity theory to educational gender gap research. Social Psychology of Education, 17(3), 357-381. https://doi.org/10.1007/s11218-014-9248-8.

Watt, H. M. (2004). Development of adolescents' self-perceptions, values, and task perceptions according to gender and domain in 7th-through 11th-grade Australian students. Child Development, 75(5), 1556-1574.

Wigfield, A., \& Eccles, J. S. (2000). Expectancy-value theory of achievement motivation. Contemporary Educational Psychology, 25, 68-81.

Wigfield, A., Eccles, J. S., Yoon, K. S., Harold, R. D., Arbreton, A. J. A., Freedman-Doan, C., et al. (1997). Change in children's competence beliefs and subjective task values across the elementary school years: A 3-year study. Journal of Educational Psychology, 89, 451-469. https://doi. org/10.1037/0022-0663.89.3.451.

Wigfield, A., \& Guthrie, J. T. (1997). Relations of children's motivation for reading to the amount and breadth of their reading. Journal of Educational Psychology, 89(3), 420-432. https://doi. org/10.1037/0022-0663.89.3.420.

Wolter, I., Braun, E., \& Hannover, B. (2015). Reading is for girls!? The negative impact of preschool teachers 'traditional gender role attitudes on boys' reading related motivation and skills. Frontiers in Psychology, 6, 1-11. https://doi.org/10.3389/fpsyg.2015.01267.

Wood, W., \& Eagly, A. H. (2009). Gender identity. In R. H. M. Leary (Ed.), Handbook of individual differences in social behavior (pp. 109-125). New York: Guilford Press.

World Bank. (2012). Informe sobre el desarrollo mundial. Panorama general: Igualdad de género y desarrollo [Global development report. Overview: Gender equality and development]. Washington, DC: International Bank for Reconstruction and Development. 
Younger, M., Warrington, M., \& Williams, J. (1999). The gender gap and classroom interactions: Reality and rhetoric? British Journal of Sociology of Education, 20, 325-341. https://doi.org/10.1080/0142569999 5290 .

Publisher's Note Springer Nature remains neutral with regard to jurisdictional claims in published maps and institutional affiliations.

Ana María Espinoza Master in Educational Psychology, and Psychology Ph.D. candidate at the School of Psychology, Pontificia Universidad Católica of Chile. Her research interests include the psychosocial factors that influence the gender gaps in education. Specifically, her research focuses on gender identity variables, and gender stereotypes related to educational processes.

Katherine Strasser Full professor, School of Psychology, Pontificia Universidad Católica de Chile. Studies development of oral and written language in early childhood and in school, gender stereotypes related to academic achievement, and teacher professional development in these topics. 